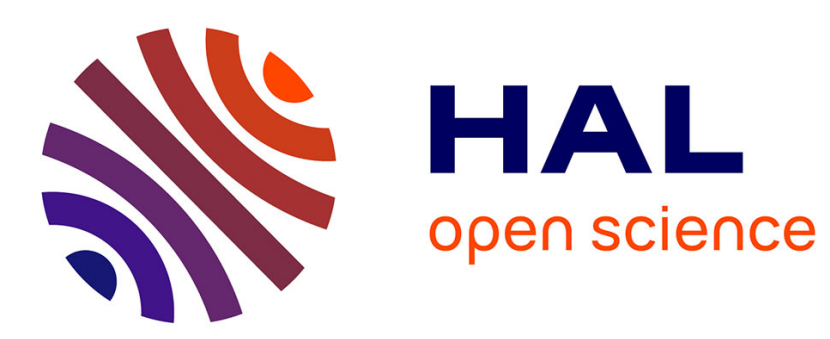

\title{
Two-Versus Three-Dimensional In Vitro Differentiation of Human Pulp Cells Into Odontoblastic Cells
}

\author{
J. Camps, I. About, B. Thonneman, T. A Mitsiadis, G. Schmaltz, J.-C. \\ Franquin
}

\section{- To cite this version:}

J. Camps, I. About, B. Thonneman, T. A Mitsiadis, G. Schmaltz, et al.. Two-Versus ThreeDimensional In Vitro Differentiation of Human Pulp Cells Into Odontoblastic Cells. Connective Tissue Research, 2009, 43 (2-3), pp.396-400. 10.1080/03008200290001069 . hal-03552451

\author{
HAL Id: hal-03552451 \\ https://hal.science/hal-03552451
}

Submitted on 2 Feb 2022

HAL is a multi-disciplinary open access archive for the deposit and dissemination of scientific research documents, whether they are published or not. The documents may come from teaching and research institutions in France or abroad, or from public or private research centers.
L'archive ouverte pluridisciplinaire HAL, est destinée au dépôt et à la diffusion de documents scientifiques de niveau recherche, publiés ou non, émanant des établissements d'enseignement et de recherche français ou étrangers, des laboratoires publics ou privés. 


\title{
Two- Versus Three-Dimensional In Vitro Differentiation of Human Pulp Cells Into Odontoblastic Cells
}

\author{
J. Camps, ${ }^{1}$ I. About, ${ }^{1}$ B. Thonneman, ${ }^{2}$ T. A. Mitsiadis, ${ }^{1}$ G. Schmaltz, ${ }^{1}$ \\ and J.-C. Franquin ${ }^{1}$ \\ ${ }^{1}$ Laboratoire IMEB, Faculté d'Odontologie, Marseille, France \\ ${ }^{2}$ Department of Operative Dentistry, Regensburg, Germany
}

\begin{abstract}
The spatial organization of the pulp cells may modify the cytodifferentiation process. The purpose of this study was to compare the two- versus three-dimensional cell culture systems for differentiation of human odontoblastic cells in vitro. Pulpal cores from freshly extracted human third molars were cultured in vitro in a perfusion device on two types of membranes: polyester membrane (twodimensional [2D] cell culture) and nylon mesh (three-dimensional [3D] cell culture). The cells were incubated with minimum essential medium containing (a) substitute serum, (b) $10 \%$ fetal calf serum (FCS), (c) $10 \%$ fetal calf serum $+2 \mathrm{mM} \beta$-glycerophosphate $(\beta G P)$, and (d) $10 \%$ fetal calf serum + transforming growth factor (TGF) $\beta 1$. Immunohistochemistry was used to evaluate the expression of collagen I, osteonectin, and nestin. Small differences were observed between 2D and 3D cell culture systems. This was particularly evident in the $10 \%$ FCS group. $\beta$-Glycerophosphate in the 3D system seems to stimulate the osteogenic cell phenotype, as a considerable induction of osteonectin is observed.
\end{abstract}

Keywords Human, Odontoblast, Cytodifferentiation, Three Dimension, Culture.

\section{INTRODUCTION}

Odontoblasts are postmitotic cells synthesizing the organic matrix of dentin. Since odontoblasts cannot be cultured in vitro by traditional cell culture methods, several innovative culture systems have been proposed [1-3]. For research purposes, dental papillae of neonatal rodents have been extensively used with success [1]. However this system is not suitable to evaluate the interactions between restorative materials used in common dentistry and pulpal cells. Pulp slices from extracted human teeth cultured for 30 days [3] or young rodent teeth [2] cultured up to 28 days behaved similar to pulpal cells in vivo, thus offering a nice model for studying the factors affecting pulp repair. However, the disadvantage of this system is that reparative dentin secretion cannot be studied; reparative dentin implies differentiation of pulp cells into odontoblasts, and this process is absent from the slices since all the preexisting odontoblasts remain intact.

In addition to that culture system, classical two-dimensional (2D) cell culture systems have been used. Pulp stem cells have been cultured in presence of various chemicals in order to induce the differentiation of pulp cells into odontoblastic cells in vitro. These cells exhibit an elongated shape and secrete several proteins that are specific to odontoblasts such as dentin sialoprotein (DSP). Differentiation of odontoblastic cells may be induced by $\beta$-glycerophosphate [4], calcium hydroxide [5], dexamethasone [6], ascorbic acid [7], and several growth factors [8, 9]. These well-established systems may reproduce the physiological and molecular events of human dentin production in vitro [10]. In spite of these in vitro models, a three-dimensional (3D) cell culture system might be useful and necessary for pulp tissue engineering [11-13] or for cytotoxicity testing [14]. This opens new fields of research based on a biological approach of dental therapy. As a matter of fact, human pulp fibroblasts have been grafted onto synthetic scaffolds [11] in order to replace dental pulp after root canal therapy [12,13]. Furthermore, the newly used pulp chamber with 3D cell cultures has been found to be a good in vitro model for testing cytotoxicity of restorative materials [14], since this system is less sensitive than conventional 2D systems.

The purpose of the present study was to compare a 2D and a 3D culture system for in vitro differentiation of human pulp cells into odontoblastic cells.

\section{MATERIALS AND METHODS}

\section{Reagents}

All materials used for culture media preparation were purchased from Gibco BRL (Life Technologies, Inc., Grand Island, 
NY) unless otherwise stated. Minimum essential medium (MEM) was supplemented with $10 \%$ fetal bovine serum, $2 \mathrm{mM}$ glutamine, $100 \mathrm{IU} / \mathrm{ml}$ penicillin, $100 \mu \mathrm{g} / \mathrm{ml}$ streptomycin (Biowhittaker, Gagny, France) and $0.25 \mu \mathrm{g} / \mathrm{ml}$ amphotericin B (Fungizone).

\section{Teeth}

Normal immature third molars freshly extracted during treatment of 16- to 18-year-old patients were used after their informed consent.

\section{Antibodies}

Rabbit polyclonal antibodies against the type I collagen were purchased from Southern Biotechnology Associates, Inc. (Birmingham, AL). Mouse monoclonal antibody to osteonectin was obtained from Takara Biochemicals (Takara Shuzo Co. Ltd., Shiga, Japan). Preparation and characterization of the polyclonal antibodies against nestin have been already described [15] and the specificity of these antibodies to human odontoblasts has been detailed [16].

\section{METHODS}

Culture of dental pulp cells was performed as previously described [10, 16]. Briefly, confluent cultures were collected by trypsinization $(0.2 \%$ trypsin and $0.02 \%$, ethylenediamine tetraacetic acid, EDTA) and subcultured for 1 month with a continuous perfusion system (Minucells and Minutissue $\mathrm{GmbH}$, Bad Abbach, Germany) at a $0.3 \mathrm{ml}$ medium $/ \mathrm{h}$ rate (Figure 1).
The MEM used was supplemented with one of the following: (a) growth factor-free serum substitute, (b) $10 \%$ fetal calf serum (FCS), (c) $10 \%$ fetal calf serum $+2 \mathrm{mM} \beta$-glycerophosphate $(\beta \mathrm{GP})$, and (d) $10 \%$ fetal calf serum + transforming growth factor (TGF) $\beta 1(5 \mathrm{ng} / \mathrm{ml})$. The cells were cultured, in the pulp chamber device (Figure 2), on two types of membranes: polyester membrane (2D cell culture) and nylon mesh (3D culture system) (Advanced Tissue Sciences, La Jolla, CA).

The culture medium was continuously perfused to mimic pulpal clearance and also to remove the by-products of the cells that may accumulate over 1 month and modify the culture conditions. The perfusion rate was calculated from a previous comparative study [13], which showed a statistically significant influence of the perfusion rate on the outcome of cytotoxicity studies. After 1 month of cell culture, the cells were fixed with $70 \%$ ethanol for $1 \mathrm{~h}$ at $4^{\circ} \mathrm{C}$ and processed for immunohistochemistry.

The cells were permeabilized for 15 min with $0.5 \%$ Triton $\mathrm{X}-100$ in phosphate-buffered saline (PBS). Primary antibodies were diluted in PBS containing $0.1 \%$ bovine serum albumin (BSA). The incubation with primary antibodies was performed overnight at $4{ }^{\circ} \mathrm{C}$ at the following concentrations: anti-collagen I antibodies were used at $40 \mu \mathrm{g} / \mathrm{ml}$, and anti-osteonectin at $50 \mu \mathrm{g} / \mathrm{ml}$. Anti-nestin antibodies were diluted 1:1500 in PBS. The immunostaining was revealed using the labeled streptavidin-biotin kit (LSAB; Dako Corporation, Carpinteria, CA) according to the manufacturer's instructions. Glycergel was used as a mounting medium (Dako Corporation, Carpinteria, CA). Controls were performed by incubations with unrelated primary antibodies.

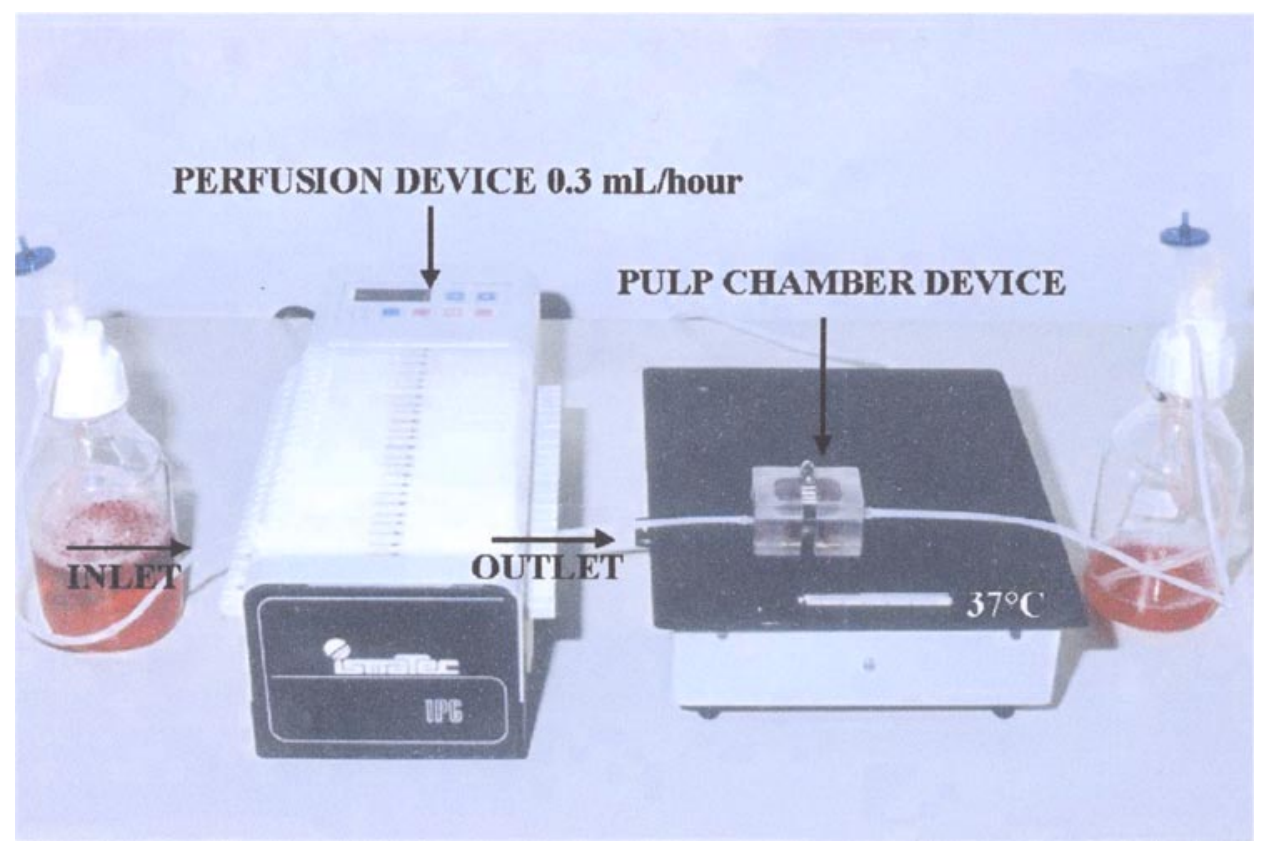

Figure 1. The perfusion system: an automatic device that allows constant renewal of the culture medium at $0.3 \mathrm{ml} / \mathrm{h}$ within the pulp chamber system. 


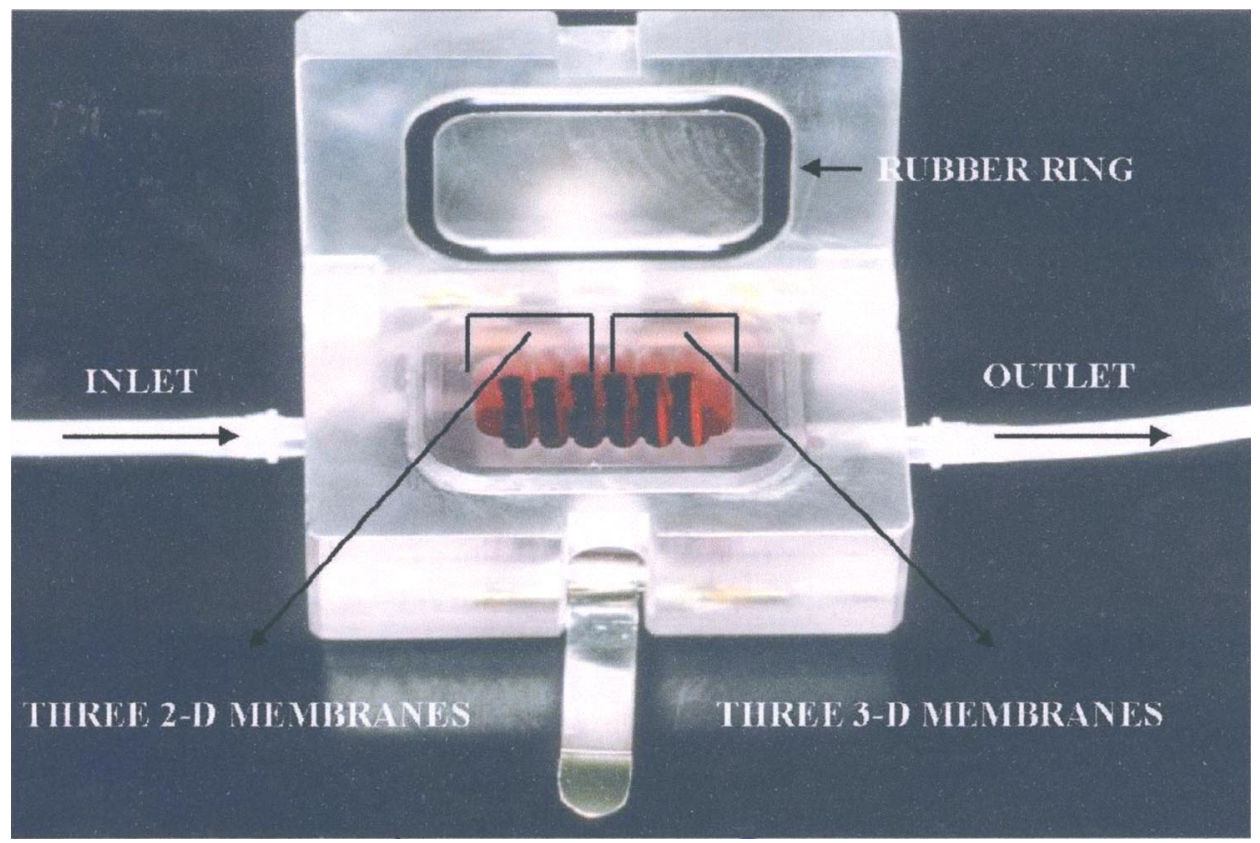

Figure 2. Polycarbonate pulp chamber system: This device contains simultaneously three $2 \mathrm{D}$ and three $3 \mathrm{D}$ membranes. The inlet is on the left side and the outlet on the right side.

\section{RESULTS AND DISCUSSION}

When the serum substitute was used, no difference between the $2 \mathrm{D}$ and the $3 \mathrm{D}$ cell culture system was found (Table 1 and Figure 3A). The cells expressed all of the proteins weakly. This means that in absence of growth factors, spatial arrangement of the cells does not influence the ability of the cells to express specific proteins. Even in the absence of growth factors, whatever their spatial arrangement is, the pulp stem cells can secrete weakly proteins specific to odontoblasts after 1 month of culture.

No difference was observed when using a serum substitute or MEM $+10 \%$ FCS on the 3D system. On the other hand, no protein was detected when using MEM $+10 \%$ FCS on the 2D system. This may indicate that FCS is not important to in vitro cell differentiation when working with a 3D cell culture system.

TABLE 1

Comparison of the immunohistochemical staining on 2D and 3D membranes.

\begin{tabular}{lcccccc}
\hline & 2D & 3D & 2D & 3D & 2D & 3D \\
& Coll I & Coll I & OSN & OSN & Nestin & Nestin \\
\hline $\begin{array}{l}\text { Serum } \\
\text { substitute }\end{array}$ & + & + & + & + & + & + \\
$\begin{array}{l}10 \% \text { FCS } \\
10 \% \text { FCS }\end{array}$ & 0 & + & 0 & + & 0 & + \\
$\quad+\beta$ GP & & + & + & ++ & + & + \\
$\begin{array}{c}10 \% \text { FCS } \\
\quad+\text { TGF } \beta 1\end{array}$ & ++ & + & ++ & ++ & ++ & ++ \\
\hline
\end{tabular}

It might also suggest that spatial arrangement is of prime importance when working with FCS alone because no protein was detected with the 2D cell culture system while all of them were weakly expressed with the 3D cell culture system (Table 1). The use of a higher concentration of FCS seems to be of prime importance in obtaining development of dental papilla in vitro similar to that obtained in vivo [17]. Fetal calf serum contains growth factors in unknown concentrations, probably varying from a batch to another. The use of $\beta \mathrm{GP}$ or TGF $\beta 1$ gives much better results to obtain in vitro differentiation of odontoblastic cells.

$\beta \mathrm{GP}$ has already been successfully used to produce human dentin in vitro [10]. $\beta \mathrm{GP}$ is metabolized by alkaline phosphatase and the combination in vitro of the phosphorus released from $\beta \mathrm{GP}$ and calcium contained in the medium permits the formation of nodules of mineralization. This permits an in vivo rapid induction of mineralization when used for direct pulp capping [18] or apical barrier formation [19]. The addition of $\beta$ GP to the medium containing $10 \%$ FCS greatly modifies the results of the study. All of the proteins tested were weakly expressed when $2 \mathrm{mM} \beta \mathrm{GP}$ was added to the medium. In the 3D system, osteonectin reactivity was much stronger in presence of $\beta$ GP. This is in favor of a 3D cell culture system when using $\beta \mathrm{GP}$ as a mineralization inductor. When direct pulp cappings are performed with calcium hydroxide, it has been shown that the calcium incorporated during hard tissue formation does not come from the calcium hydroxide itself but rather from the pulp blood flow (20). Therefore, in the same way, $\beta$ GP probably does not only act as a source of phosphorus but could be involved in the odontoblast cells differentiation. This has 

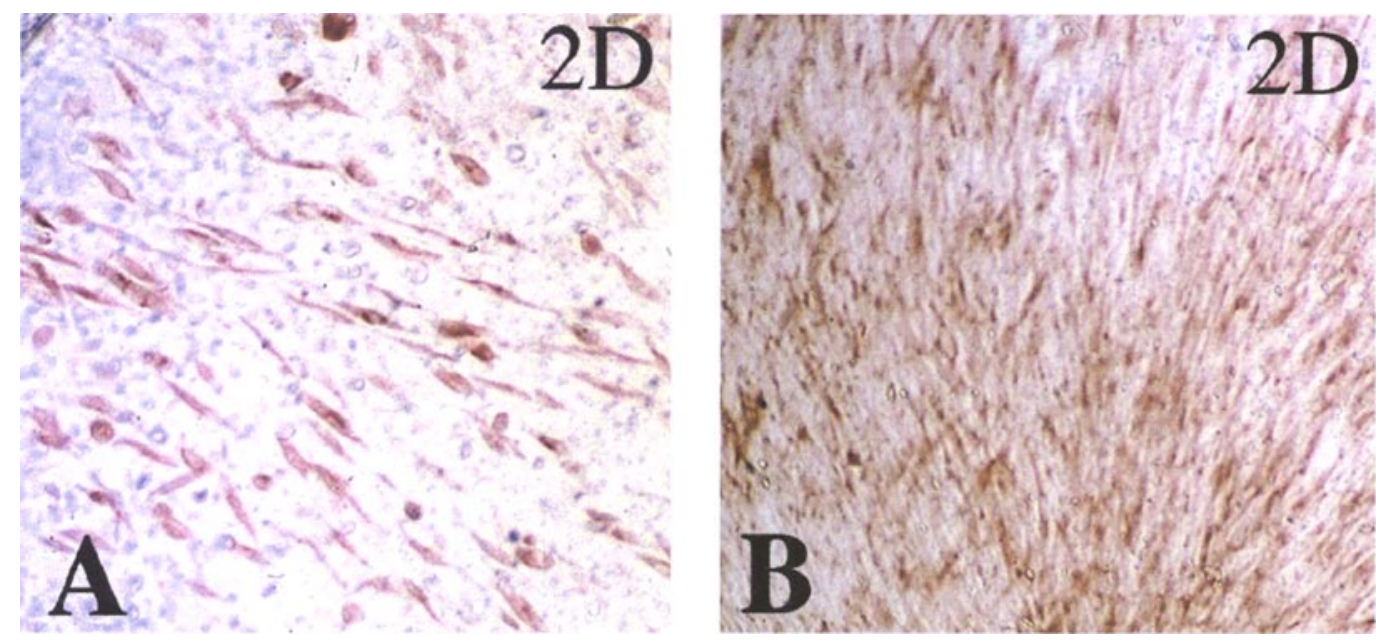

Figure 3. Immunohistochemical detection of osteonectin in the $2 \mathrm{D}$ culture system in the presence of either replacement serum (A) or $10 \%$ FCS/TGF $\beta 1$ (B).

been suggested in earlier studies on cultured human pulp cells where the addition of $\beta$ GP to pulp cells cultivated with $10 \%$ FCS induced the odontoblastic differentiation while in the absence of $\beta \mathrm{GP}$ no odontoblastic differentiation was observed $[10,21]$. Although growth factors could be present in the serum, the addition of $\beta \mathrm{GP}$ seems to be determinant in this differentiation process even if the mechanism remains to be elucidated.

When TGF $\beta 1$ was added to the medium, no difference was found between the 2D and the 3D cell culture systems except for collagen type I that was more expressed in the 2D culture system. Nestin and osteonectin were strongly expressed in both 2D and 3D systems (Table 1 and Figure 3B).

Under the culture conditions of this study, mineralization nodules were not observed. This may be due to the fact that the medium flow disturbs the crystal growth and renders their formation impossible. When working with growth factors to induce in vitro cytodifferentiation the $3 \mathrm{D}$ cell culture system does not bring any advantage over the 2D system.

In conclusion, the $3 \mathrm{D}$ system brings advantages over the $2 \mathrm{D}$ system only when working with $10 \%$ FCS. When TGF $\beta 1$ is added to the medium the 3D system does not bring any advantage. Therefore we can recommend either the use of a 3D system when working with $10 \% \mathrm{FCS}$ or the use of $\beta \mathrm{GP}$ associated to $\mathrm{TGF} \beta 1$ to induce differentiation of odontoblastic cells and to allow them to secrete dentin.

\section{REFERENCES}

[1] Lesot, H., Osman, M., and Ruch, J.V. (1981). Immunofluorescent localization of collagens, fibronectins, and laminin during terminal differentiation of odontoblasts. Dev. Biol. 82:371-381.

[2] Sloan, A.J., Shelton, R.M., Hann, A.C., Moxham, B.J., and Smith, A.J. (1998). An in vitro approach for the study of dentinogenesis by organ culture of the dentine-pulp complex from rat incisor teeth. Arch. Oral Biol. 43:421-430.

[3] Magloire, H., Joffre, A., and Bleicher, F. (1996). An in vitro model of human dental pulp repair. Dent. Res. 75:1971-1978.
[4] Hao, J.J., Shi, J.N., Niu, Z.Y., Yue, L., and Xiao, M.Z. (1997). Mineralized nodule formation by human dental papilla cells in culture. Eur. J. Oral Sci. 105:318-324.

[5] Seux, D., Couble, M.L., Hartmann, D.J., Gauthier, J.P., and Magloire, H. (1991). Odontoblast-like cytodifferentiation of human dental pulp cells in vitro in the presence of a calcium hydroxide-containing cement. Arch. Oral Biol. 36:117-128.

[6] Kasugai, S., Shibata, S., Suzuki, S., Susami, T., and Ogura, H. (1993). Characterization of a system of mineralzed-tissue formation by rat dental pulp cells in culture. Arch. Oral Biol. 38:769-777.

[7] Satoyoshi, M., Koizumi, T., Teranaka, T., Iwamoto, T., Takita, H., Yuboki, Y., Saito, S., and Mikuni-takagaki, Y. (1995). Extracellular processing of dentin matrix protein in the mineralising odontoblast culture. Calcif. Tissue Int. 57:237-241.

[8] Toyono, T., Nakashima, M., Kuhara, S., and Akamine, A. (1997). Temporal changes in the expression of transforming growth factor- $\beta$ superfamily members and their receptors during bovine preodontoblast differentiation in vitro. Arch. Oral Biol. 42:481-488.

[9] Shiba, H., Nakamura, S., Shirakawa, M., Nakanishi, K., Okamoto, H., Satakeda, H., Noshiro, M., Kamigashi, K., Katayama, M., and Kato, Y. (1995). Effects of basic fibroblast growth facto on proliferation, the expression of osteonectin (SPARC) and alkaline phosphatase, and calcification in cultures of human pulp cells. Dev. Biol. 170:457-466.

[10] About, I., Bottero, M.-J., de Denato, P., Camps, J., Franquin, J.-C., and Mitsiadis, T.A. (2000). Human dentin production in vitro. Exp. Cell Res. 258:33-41.

[11] Mooney, D.J., Powell, C., Piana, J., and Rutherford, B. (1996). Engineering dental pulp-like tissue in vitro. Biotechnol. Prog. 12:865-868.

[12] Buurma, B., Gu, K., and Rutherford, R. (1999). Transplantation of human pulpal and gingival fibroblasts attached to synthetic scaffolds. Eur. J. Oral Sci. 107:282-289.

[13] Bohl, K.S., Shon, J., Tutherford, B., and Moony, D. (1998). Role of extracellular matrix in the development of engineered dental pulp. J. Biomater. Sci. Polymer. Ed. 9:749-764.

[14] Schmalz, G., Schuster, U., Nuetzel, K., and Schweikl, H. (1999). An in vitro pulp chamber with three-dimensional cell cultures. J. Endodont. 25:24-29.

[15] Lendahl, U., Zimmerman, L.B., and McKay, R.D.G. (1990). CNS stem cells express a new class of intermediate filament protein. Cell 60:585595 .

[16] About, I., Laurent-Maquin, D., Lendahl, U., and Mitsiadis, T.A. (2000). Nestin expression in embryonic and adult human teeth under normal and pathological conditions. Am. J. Pathol. 157(1):287-295. 
[17] Young, W.G., Ruch, J.V., Stevens, M.R., Bègue-Kirn, C., Zhang, C.Z., Lesot, H. et al. (1995). Comparison of the effects of growth hormone insulin-like growth factor-I and fetal calf serum on mouse molar odontogenesis in vitro. Arch. Oral Biol. 40:789799 .

[18] Hayashi, I.M. (1993). Ultrastructure of wound healing following direct pulp capping with calcium- $\beta$-glycerophosphate (Ca-BGP). J. Oral Pathol. Med. 27:411-417.
[19] Viloria, I.L., Yanaguguchi, K., and Hayashi, Y. (2000). Structure and chemical composition of an experimentaly formed apical barrier after the application of calcium-glycerophosphate. J. Endodont. 26:605-608.

[20] Pisanti, S., and Sciaky, I. (1964). Origin of calcium in the repair wall after pulp exposure in dog. J. Dent. Res. 43:641-644.

[21] Couble, M.L., Farges, J.C., Bleicher, F., Perrat-Mabillon, B., Boudeulle, M., and Magloire, H. (2000). Odontoblast differentiation of human dental pulp cells in explant cultures. Calcif. Tissue Int. 66(2):129-138. 